\title{
SISTEM PENDUKUNG KEPUTUSAN PROMOSI PEJABAT STRUKTURAL MELALUI DIKLAT KEPEMIMPINAN IV MENGGUNAKAN METODE PROFILE MATCHING STUDI KASUS DI PPPPTK BAHASA JAKARTA
}

\author{
DECISION SUPPORT SYSTEM OF STRUCTURAL POST PROMOTION THROUGH LEADERSHIP TRAIN- \\ ING AND EDUCATION IV BY USING MATCHING PROFILE METHOD A CASE STUDY IN PPPPTK BA- \\ HASA JAKARTA
}

\author{
Yulia Purwaningsih"11 dan Raden Supriyanto*) \\ *) Jurusan Sistem Informasi, Fakultas Ilmu Komputer dan Teknologi Informasi, Universitas Gunadarma \\ Jl. Margonda Raya 100 Pondok Cina, Depok, Jawa Barat, Indonesia
}

\begin{abstract}
This research attempted to develop an executive decision support system for structural promotion that precise, fast, and systematic; as well as to establish employee databases for performance assessment. The research employed 1) descriptive analyses to identify the promotion problem in PPPPTK Bahasa; 2) data analyses to explore the collected data from observation, questionnaire, and interview; and 3) waterfall model which is known as classical life cycle model and systematic approach in sequence to develop a software. The development design started with analyses, design, coding, testing, and maintenance. Results indicate that the executive decision support system for structural promotion was successfully developed to meet the objective, and the output can be used for decision and employee performance database. The study concluded that the decision support system for structural promotion increased effective and efficient decision making. This system was created on the data that followed human resources norms in PPPPTK Bahasa. The system provided a recommendation based on evaluation for employee promotion based on their performance ranks.
\end{abstract}

Keywords: gap analysis, leadership training, profile matching, post promotion, decision support system

\begin{abstract}
Abstrak: Penelitian ini bertujuan mengembangkan sebuah sistem penunjang keputusan dalam proses promosi jabatan struktural untuk membantu pimpinan dalam mengambil keputusan secara tepat, cepat, dan sistematis; dan membuat basis data (database) pegawai untuk sistem penilaian kinerja pegawai. Metode yang digunakan dalam penelitian ini adalah 1) identifikasi masalah promosi jabatan pegawai PPPPTK Bahasa dengan menggunakan analisis deskriptif; 2) analisis data masukan dari proses observasi, data kuesioner dan hasil wawancara; dan 3) pengembangan perangkat lunak menggunakan model air terjun atau sering disebut dengan siklus kehidupan klasik, pendekatan yang sistematis dalam sekuensial. Pengembangan dimulai dari analisis, desain, kode, pengujian, dan pemeliharaan. Hasil penelitian menunjukkan bahwa sistem pendukung keputusan promosi jabatan struktural berhasil dikembangkan sesuai dengan tujuan dan hasil keluaran sistem yang dapat digunakan sebagai masukan bagi pimpinan dalam pengambilan keputusan serta dapat disimpan sebagai basis data penilaian kinerja pegawai. Simpulan yang dapat ditarik dari hasil penelitian ini adalah Sistem Pendukung Keputusan Promosi Jabatan Struktural mampu meningkatkan keefektifan dan efisiensi manajemen dalam pengambilan keputusan. Sistem ini dibuat berdasarkan data dan norma-norma sumber daya manusia (SDM) di Pusat Pengembangan dan Pemberdayaan Pendidik dan Tenaga Kependidikan (PPPPTK) Bahasa. Sistem penunjang keputusan yang mampu memberikan evaluasi kinerja pegawai yang akan dipromosikan berupa pemeringkatan pegawai sebagai rekomendasi bagi pimpinan untuk mengambil keputusan.
\end{abstract}

Kata kunci: analisis gap, diklat kepemimpinan, profile matching, promosi jabatan, sistem penunjang keputusan

\footnotetext{
${ }^{1}$ Corresponding author:

Email: lia13102011@gmail.com
} 


\section{PENDAHULUAN}

Sumber daya manusia memainkan peranan yang sangat penting dalam mewujudkan organisasi yang ideal. Hal ini perlu mendapat perhatian dan pengkajian yang lebih mendalam karena pada akhirnya manusia juga yang menentukan dan memprediksi keberhasilan atau kegagalan suatu kebijakan, strategi, proses bisnis, dan alur kerja sebuah organisasi (Sjafri, 2009). Menurut Rivai (2005) pegawai merupakan sumber daya manusia (SDM) yang berperan sebagai penggerak organisasi dalam rangka mencapai tujuan organisasi. Dalam pengelolaan sumber daya manusia, promosi jabatan merupakan faktor penting. Adalah bukan perkara yang mudah untuk menempatkan seseorang yang tepat dalam suatu jabatan (Schermerhorn et al. 1996). Pusat Pengembangan dan Pemberdayaan Pendidik dan Tenaga Kependidikan (PPPPTK) Bahasa merupakan salah satu unit pelaksana teknis (UPT) di Kementerian Pendidikan dan Kebudayaan yang juga mempunyai kendala dalam pengelolaan sumber daya manusia. Salah satu kendala itu adalah bahwa seleksi promosi jabatan masih dilakukan secara manual sehingga diperlukan waktu yang cukup lama untuk membuat sebuah keputusan agar dapat diterima oleh pihakpihak yang berkepentingan (Qomayati, 2010). Secara lebih spesifik, penilaian pegawai hanya didasarkan pada faktor tertentu, seperti tingkat pendidikan, masa kerja, dan golongan. Padahal, masih ada faktor lain untuk menilai pegawai, seperti pengetahuan, budaya perusahaan, kemampuan, dan kepribadian. Faktorfaktor tersebut dapat menjadi masukan (input) sebuah sistem yang dapat membantu dalam pengambilan keputusan. Oleh karena itu, perlu adanya sebuah sistem penunjang keputusan.

Sistem Pendukung Keputusan merupakan suatu pendekatan untuk mendukung pengambilan keputusan dimana dapat menyelesaikan problem yang kompleks, selain itu sistem dapat berinteraksi dengan pemakainya dan prosesnya lebih cepat dengan hasil yang lebih baik (terutama dibandingkan dengan pengambilan keputusan secara intuisi) serta menghasilkan acuan data untuk menyelesaikan masalah yang dihadapi oleh manajer yang kurang berpengalaman dan untuk masalah yang berulang (Turban, 2005). Sistem penunjang keputusan dimaksudkan untuk membantu para pengambil keputusan dalam rangka penilaian kinerja pegawai secara objektif berdasarkan standar yang telah ditetapkan. Penilaian yang baik akan menghapus subjektifitas sehingga diharapkan kesenjangan antarpegawai tidak akan terjadi dan juga akan memberikan motivasi kepada seluruh pegawai untuk memberikan yang terbaik kepada perusahaan atau lembaga (Firman, 2014).

Kajian penelitian terdahulu kebanyakan membahas proses seleksi promosi jabatan dengan beberapa nama jabatan dengan menggunakan kriteria jabatan yang sama, dan tidak spesifik. Padahal, setiap jabatan memiliki karakteristik yang berbeda dan tentunya membutuhkan kriteria yang berbeda pula. Oleh karena itu, penetapan dan jumlah kriteria harus diperhitungkan. Dengan banyaknya jenis atau nama jabatan, semestinya kriteria dibedakan dengan bergantung pada syarat jabatan pada profil jabatan agar hasilnya sesuai dengan yang diharapkan. Sebuah penelitian tentang Penerapan Metode Profile Matching dalam Sistem Pendukung Keputusan Penilaian Kinerja Karyawan (Studi Kasus PT. Perkebunan Nusantara III Medan) yang dilakukan Puspitasari (2013) mengungkap dua aspek yang dibutuhkan dalam proses seleksi, yaitu kapasitas intelektual dan sikap kerja. Dalam prosesnya dibandingkan dengan data ideal yang sudah ditetapkan kemudian diberikan bobot nilai yang jika karyawan memiliki bobot nilai paling besar dialah yang berhak mendapat penghargaan. Penelitian menghasilkan pemeringkatan karyawan yang memiliki kinerja baik.

Penelitian lain yang serupa dengan penelitian terdahulu dilakukan oleh Muqtadir dan Purdianto (2013) tentang Sistem Pendukung Keputusan Kenaikan Jabatan Menggunakan Metode Profile Matching (Studi Kasus PT. Industri Kemasan Semen Gresik). Penelitian ini menghasilkan sebuah sistem pendukung keputusan untuk menyeleksi karyawan yang cocok untuk mengisi jabatan kosong secara cepat dan objektif di PT. IKSG. Penelitian ini hampir mirip dengan yang dilakukan penulis, yang prosesnya menggunakan metode Profile Matching dan analisis gap. Perbedaannya terletak pada jumlah dan nama jabatan yang akan diisi. Pada penelitian terdahulu sistem digunakan untuk mengisi banyak nama jabatan seperti Kepala Bagian Niaga, Kepala Regu Keuangan sedangkan penelitian ini hanya berfokus pada satu jenis jabatan.

Kajian yang dilakukan oleh Muchsam et al. (2011) tentang Penerapan Gap Analysis pada Pengembangan Sistem Pendukung Keputusan Penilaian Kinerja Karyawan (Studi Kasus PT. XYZ) menyajikan penelitian pengelolaan karier karyawan dengan penilaian yang transparan dan jauh dari faktor 
subjektivitas manajemen terkait dengan pengembangan karier karyawan. Sistem yang dibuat dirancang untuk dapat dioperasikan oleh tiga pengguna, yaitu HRD, supervisor, dan karyawan. Hasil penelitian ini dapat meningkatkan motivasi karyawan untuk berprestasi dan bahan evaluasi bagi manajemen untuk mengambil tindakan dalam meningkatkan kinerja karyawan. Yang membedakan penelitian Muchsam et al. dengan penelitian ini adalah bahwa penelitian Muchsam menggunakan tiga pengguna sedangkan penelitian ini menggunakan satu pengguna, yakni staf HRD. Dengan demikian, karyawan tidak perlu mengetahui hasil penilaian dirinya karena hal ini bersifat rahasia, dan atasan akan mendapat laporan/hasil keluaran dari sistem.

Hidayat et al. (2013) mengkaji Sistem Pendukung Keputusan Evaluasi Kinerja Karyawan untuk Promosi Jabatan Struktural pada Bimbingan Belajar Sciencemaster dengan Metode Gap Kompetensi (Profile Matching). Penelitian ini menghasilkan pemeringkatan karyawan yang akan ditempatkan pada jabatan tertentu. Peneliti menggunakan tes psikologi IST (Intelligenz Strukturen Teztie) sebagai kriteria Kecerdasan dan tes Pauli untuk kriteria Sikap Kerja. Dalam penelitian ini, penulis menggunakan proses penilaian yang digabungkan dengan menggunakan tes psikologi.

Penelitian yang dilakukan Palandi dan Pusyastuti (2014) tentang Penyaringan Kandidat untuk Promosi Jabatan dengan Profile Matching mengungkap cara dan proses pengambilan keputusan untuk promosi jabatan di STIKI yang membutuhkan waktu lama dan kelemahan sistem lama yang penilaian kinerja karyawan dinilai tidak adil. Hasil penelitian dapat digunakan untuk menentukan sanksi dan penghargaan bagi karyawan yang kinerjanya baik sehingga berpeluang mengisi jabatan tertentu. Penelitian ini menggabungkan proses penilaian dan tes psikologi.

Penelitian yang dilakukan oleh Wicaksono (2014) tentang Sistem Pendukung Keputusan Kenaikan Jabatan Struktural dengan Metode Profile Matching pada Karyawan Universitas Negeri Semarang membahas pengambilan keputusan yang dilakukan secara manual, yaitu tidak adanya penilaian kinerja yang dilakukan secara pasti, dalam hal ini hanya dilakukan secara sepihak, tidak ada standar baku atau bobot nilai dalam menentukan kualitas pegawai. Proses Profile Matching menggunakan lima aspek dasar yaitu hasil tes, pengalaman, diklat, senioritas, dan usia. Penelitian ini menghasilkan sistem berbasis laman (web) yang dapat membantu proses kenaikan jabatan struktural pada Universitas Negeri Semarang. Kristiana (2015) dengan judul Penerapan Profile Matching untuk Penilaian Kinerja Pegawai Negeri Sipil (PNS) membahas pentingnya peran SDM dalam rangka pencapaian tujuan sebuah lembaga pemerintahan. Penghargaan Abdi Karya diberikan pada PNS Litbang yang jujur, setia, dan taat kepada bangsa dan negara, didiplin serta menunjukkan prestasi kerja yang baik untuk menjadi teladan bagi PNS lainnya. Penelitian ini menghasilkan sistem yang dapat digunakan untuk melakukan penilaian kinerja pegawai apakah seorang pegawai yang bersangkutan layak mendapat penghargaan Abdi Karya.

Kusnadi etal. (2015) mengenai Penerapan Metode Profile Matching untuk Penilaian Kenaikan Jabatan Karyawan (Studi Kasus PT. Ilham Bangun Mandiri) menjelaskan pemilihan karyawan yang sesuai dengan kriteria suatu jabatan. Metode Profile Matching menggunakan tiga aspek penilaian yaitu kinerja, sikap kerja, dan perilaku. Penelitian ini menghasilkan sistem yang dapat mempermudah penentuan kelayakan posisi karyawan. Kajian Ariantono et al. (2015) tentang Rancang Bangun Sistem Pendukung Keputusan Penentuan Kenaikan Posisi Jabatan pada Instansi Pemerintahan dengan Metode Profile Matching menjelaskan masalah yang sama yaitu kendala dalam pemilihan orang-orang yang memiliki kualifikasi yang dibutuhkan untuk mengisi jabatan sebuah organisasi. Sistem yang dihasilkan dapat melakukan pekerjaan yang sebelumnya dilakukan secara sederhana. Kajian Lestari (2016) tentang Perancangan Aplikasi Peningkatan Jenjang Karier Menggunakan Metode Profile Matching (Studi Kasus: CV. Indaco Tranding Company) membahas proses kenaikan jabatan yang lama dan masih dengan cara manual. Penelitian ini menghasilkan sebuah sistem yang mempermudah kerja bagian SDM dalam memproses kenaikan jabatan karyawan.

Penelitian yang dilakukan Deny (2014) tentang Sistem Pendukung Keputusan Pengangkatan Jabatan Karyawan padaPT.Ayn dengan Metode Profile Matching membahas masalah subyektifitas dalam penilaian kinerja pegawai. Sistem yang dihasilkan dapat menghindari subyektifitas dan memberikan masukan bagi manajemen khususnya Biro Umum dan Kepegawaian dalam membuat keputusan yang tepat bagi pengembangan potensi setiap pegawai. 
Dalam kajian yang dilakukan Frieyadie (2016) tentang Penggunaan Metode Profile Matching untuk Sistem Penunjang Keputusan Kenaikan Jabatan pada Instansi Pemerintah membahas masalah kenaikan jabatan dalam rangka perencanaan karier pegawai, sistem penilaian manual yang digunakan selama ini menimbulkan kecemburuan sosial antarpegawai yang nantinya akan berdampak buruk pada pencapaian tujuan sebuah perusahaan. Penelitian ini menghasilkan sistem yang mampu memberikan masukan pada pimpinan dalam mengambil keputusan yang adil bagi setiap pegawai.

Penelitian selanjutnya pernah dilakukan oleh Astriratma et al. (2017) tentang SPK Rekomendasi Pemilihan KandidatPejabatStrukturalMenggunakanMetodeProfile Matching (Studi Kasus: Pemerintah Kota Tarakan) yang membahas penempatan PNS dalam jabatan struktural berdasarkan pertimbangan objektif antara kompetensi, kualifikasi, dan persyaratan yang dibutuhkan oleh jabatan. Tim Baperjakat dalam instansi yang bertugas menilai kinerja pegawai apakah layak menduduki jabatan belum mampu memberikan argumentasi berupa data dan informasi yang memberikan pertimbangan kepada pejabat pembina kepegawaian dalam rangka pemilihan kandidat eselon IIIb ke bawah sesuai peraturan yang berlaku. Penelitian ini menghasilkan sebuah sistem yang memberikan informasi untuk menguatkan argumen dalam rangka penempatan PNS dan meminimalisasi terjadinya keputusan yang subjektif.

Dalam penelitian Handayani (2017) mengenai Sistem Pendukung Keputusan Pemilihan Karyawan Berprestasi dengan Metode Profile Matching pada PT. Sarana Inti Persada (SIP) dijelaskan pemilihan karyawan berprestasi untuk meningkatkan kinerja perusahan. Penilaian yang dilakukan selama ini masih bersifat subjektif karena terbatasnya waktu dan kemampuan melihat segala aspek yang akurat. Penelitian ini berhasil membangun sebuah sistem yang mampu menjawab permasalahan tersebut, keluaran sistem berupa laporan pemeringkatan pegawai yang berprestasi sehingga mempermudah manajemen dalam menentukan karyawannya yang berprestasi untuk mendapat penghargaan.

Penelitian mengenai penilaian kinerja pegawai juga dilakukan oleh Yunika (2017) dengan judul Sistem Pendukung Keputusan dengan Metode Analisis Gap untuk Proses Kenaikan Jabatan dan Perencanaan Karier dan menjelaskan pengisian jabatan kosong yang mengalami kesulitan karena pemilihan kandidat dan profil jabatan yang kosong kurang terdefinisi dengan baik. Sebuah sistem diperlukan untuk meminimumkan kendala tersebut. Pada akhir penelitian berhasil dibangun sebuah sistem menggunakan Microsoft Access 2010 untuk database dan Borland Delphi 7 sebagai compilernya, dan sistem ini berhasil membantu pimpinan mengambil keputusan. Aplikasi yang dibangun pada penelitian ini menggunakan mySQL dan PHP.

Semua hasil penelitian yang terbentang di atas menggunakan metode Profile Matching. Demikian pula penelitian ini. Akan tetapi, penelitian ini hanya menggunakan metode Profile Matching untuk mengisi satu jenis jabatan yang setara, yaitu jabatan eselon IV. Karena hanya satu jenis jabatan promosi, profil jabatannya sama sehingga kriteria yang digunakan pun sama. Satu jabatan dengan kriteria yang sama akan lebih sederhana prosesnya daripada banyak jabatan dengan kriteria yang sama. Akibatnya, kemungkinan hasilnya tidak maksimal karena menyamaratakan kriteria pada semua jenis jabatan. Dalam penelitian ini digunakan tiga kriteria yang sudah mewakili syarat jabatan sesuai dengan Keputusan Kepala LAN Nomor 1 Tahun 2004 tentang Pedoman Seleksi Calon Peserta Pendidikan dan Pelatihan Kepemimpinan dan Keputusan Kepala BKN Nomor 43/Kep/2001 tentang Standar Kompetensi Jabatan Eselon III dan IV. Data kriteria diperoleh melalui kuesioner yang diisi oleh pegawai yang secara administratif telah memenuhi persyaratan seperti syarat pangkat dan golongan, masa kerja, dan pendidikan. Jumlah responden adalah 30 orang pegawai PPPTK Bahasa.

Sistem yang dibangun akan membantu pimpinan dalam melakukan pemilihan pegawai yang akan dipromosikan menduduki jabatan eleson IV. Data kriteria pegawai dapat dengan cepat diperoleh dan diproses pada sistem penunjang keputusan, hal ini tentunya dapat menjawab permasalahan organisasi yang pengambilan keputusan dapat dilakukan dengan data pendukung yang terkomputerisasi dengan hasil yang dapat diterima oleh semua pihak karena penilaian tidak subjektivitas dengan kriteria penilaian yang sesuai dengan profil jabatan yang dipromosikan.

Satu hal yang membedakan penelitian ini dengan penelitian sebelumnya terletak pada adalah spesifikasi jabatan. Penelitian ini membahas satu jenis jabatan yang setara yaitu jabatan eselon IV. Karena hanya satu jenis jabatan promosi, profil jabatannya sama sehingga dapat menggunakan kriteria yang sama. Satu jabatan dengan kriteria yang sama akan lebih sederhana prosesnya. 
Permasalahan yang timbul kemudian dalam penelitian ini adalah 1) apakah dapat dikembangkan sebuah sistem penunjang keputusan dalam proses evaluasi kinerja pegawai yang diharapkan dapat membantu pimpinan dalam mengambil keputusan secara tepat dan cepat dengan proses yang sistematis; 2) apakah sistem yang dikembangkan tersebut dapat menjawab kebutuhan instansi, dalam hal ini PPPPTK Bahasa; 3) apakah data dan hasil dari sistem yang dikembangkan tersebut dapat digunakan dalam rangka pengembangan karier pegawai di PPPPTK Bahasa.

Salah satu model pendekatan dalam system penunjang keputusan promosi jabatan adalah Profile Matching. Profile Matching, sebagaimana dinyatakan oleh Handojo et al. (2003), adalah metode memecahkan sebuah masalah dengan sistem komputasi dengan cara memasukkan kriteria tertentu sebagai dasar penilaian, dan sistem secara otomatis akan mengolah data jika ada input data untuk dibandingkan dengan kriteria ideal untuk menghasilkan keputusan terbaik berdasarkan kriteria; hasilnya digunakan sebagai pertimbangan dalam mengambil keputusan oleh para pengambil keputusan atau pimpinan. Dari pembandingkan antara kompetensi individu dan kompetensi jabatan itu dapat diketahui perbedaan kompetensinya (disebut juga gap). Semakin kecil gap yang dihasilkan, semakin besar bobot nilainya, yang berarti memiliki peluang lebih besar untuk pegawai yang akan dipromosikan. Dalam Profile Matching, yang merupakan suatu proses dalam manajemen SDM, ditentukan terlebih dahulu kompetensi (kemampuan) yang diperlukan oleh suatu jabatan (Kusrini, 2007). Kompetensi atau kemampuan tersebut haruslah dapat dipenuhi oleh pemegang jabatan. Penelitian ini menggunakan metode Profile Matching. Metode ini digunakan karena paling sesuai untuk mengambil keputusan yang berhubungan dengan nilai prestasi, dan untuk membandingkan antar kompetensi individu ke dalam kompetensi suatu jabatan. Ada lima langkah dalam Profile Matching, yakni pemetaan gap kompetensi, pembobotan gap, Penghitungan dan pengelompokan core dan secondary factor, Penghitungan total nilai kriteria, Penghitungan penentuan peringkat.

Layak dinyatakan bahwa penilaian kinerja pegawai diperlukan untuk mengevaluasi kinerja pegawai dalam rangka pemberian penghargaan dan peningkatan jenjang karier berupa kenaikan jabatan. Oleh karena itu, penelitian ini membahas penilaian kinerja sebagai bahan kajiannya. Penilaian pegawai dilakukan dengan menggunakan sistem untuk menghindari subjektivitas yang selama ini menjadi masalah mendasar. Metode Profile Matching digunakan karena ia sesuai untuk pengambilan keputusan berkenaan dengan nilai prestasi. Metode ini juga dapat digunakan untuk membandingkan antarkompetensi individu ke dalam kompetensi suatu jabatan.

Aspek penilaian yang merupakan bagian penting dalam Profile Matching ditetapkan sesuai kebutuhan dan norma pada suatu instansi atau perusahaan. Aspek penilaian yang ditetapkan mewakili kriteria yang dibutuhkan bagi sebuah perusahaan dalam rangka pengembangan sumber daya manusia. Oleh karena itu, penetapan dan jumlah kriteria harus diperhitungkan. Dengan banyaknya jenis jabatan, semestinya kriteria jabatan dibedakan berdasarkan syarat jabatan pada profil jabatan agar hasil sesuai harapan.

Berpijak dari permasalahan yang telah dirumuskan, penelitian ini bertujuan mengembangkan sebuah sistem penunjang keputusan dalam proses evaluasi kinerja pegawai untuk membantu pimpinan di PРPPTK Bahasa dalam mengambil keputusan secara tepat, cepat, dan sistematis; serta membuat basis data (database) pegawai untuk sistem penilaian kinerja pegawai sehingga data dan hasil dari sistem yang dikembangkan tersebut dapat digunakan dalam rangka pengembangan karier pegawai di PPPPTK Bahasa.

\section{METODE PENELITIAN}

Penelitian ini dilakukan di PPPPTK Bahasa Jakarta yang beralamat di Jalan Gardu RT 10 RW 02, Srengseng Sawah, Jagakarsa, Jakarta Selatan. Waktu pengambilan data dilakukan dari Maret sampai Mei 2017. Data penelitian ini bersumber dari daftar urutan kepangkatan (DUK) pegawai PPPPTK Bahasa. Data yang dijadikan analisis adalah kepangkatan, pendidikan terakhir, usia, dan masa kerja pegawai. Metode penentuan sampel yang digunakan adalah non probability sampling, yaitu sampel yang dipilih berdasarkan pertimbanganpertimbangan tertentu. Sampel pada penelitian ini adalah pegawai yang memenuhi persyaratan administrasi untuk menduduki jabatan struktural eselon IV. Teknik pengambilan sampel dilakukan dengan metode convenience sampling. Untuk penelitian ini digunakan 30 responden. Pengumpulan data dilakukan melalui self administered questionnaire, yaitu teknik pengambilan data dengan menyerahkan 
atau mengirimkan daftar pertanyaan untuk diisi sendiri oleh responden. Menurut Sumarwan (2011), kuesioner merupakan serangkaian pertanyaan yang diberikan kepada responden yang responden diminta memberikan jawaban atas pertanyaan tersebut. Teknik penskalaan yang digunakan adalah skala Likert yang menggunakan skala $1-5$.

Pengumpulan data juga dilakukan dengan cara studi pustaka, dengan membaca dokumen-dokumen pendukung meliputi jurnal ilmiah, skripsi, tesis, disertasi, artikel, serta dokumen-dokumen pendukung lainnya yang berhubungan dengan penelitian ini. Dilakukan juga observasi lapangan dan wawancara denganKepalaSubbagian Tatalaksanadan Kepegawaian PPPPTK Bahasa yang mempunyai tugas dan fungsi memproses promosi jabatan pegawai. PHP Hypertext Preprocessor dipilih sebagai bahasa pemodelan dalam pengembangan sistem dan data yang dibangun dikelola MySQL.

Pendekatan yang digunakan dalam penelitian ini adalah pendekatan kuantitatif dengan metode penelitian deskriptif. Berkenaan dengan ini, Hadari (2003), metode deskriptif yaitu metode-metode penelitian yang memusatkan perhatian pada masalahmasalah atau fenomena yang bersifat aktual pada saat penelitian dilakukan, kemudian menggambarkan faktafakta tentang masalah yang diselidiki sebagaimana adanya diiringi dengan interprestasi yang rasional dan akurat. Penelitian ini memiliki tiga variabel, yakni faktor pengetahuan dan budaya perusahaan, faktor kemampuan, dan faktor kepribadian.
Perancangan sistem penunjang keputusan ini menggunakan model air terjun atau sering disebut siklus kehidupan klasik. Model perancangan sistem air terjun ini memerlukan pendekatan yang sistematis dalam sekuensial di dalam pengembangan sistem perangkat lunak (Jogiyanto, 2005). Pengembangan sistem tersebut dimulai dari analisis, desain, kode, pengujian, hingga pemeliharaan, sebagaimana terbentang dalam Gambar 1. Gambar tersebut menunjukkan bahwa hal pertama yang harus dilakukan dalam pengembangan sistem adalah mengidentifikasi masalah yang sedang terjadi di dalam organisasi, mempelajari berkas fisik terutama pada masalah proses promosi jabatan di PPPPTK Bahasa, yang saat ini masih sederhana karena hanya berdasarkan masa kerja dan syarat administrasi. Ada empat masalah yang diidentifikasi. Pertama, proses promosi jabatan masih menggunakan cara sederhana. Kedua, penentuan pegawai yang layak untuk promosi jabatan relatif menyita waktu. Ketiga, kemungkinan kesalahan dan kehilangan arsip dapat terjadi. Keempat, kemungkinan ada subjektivitas pimpinan dan rasa tidak adil bagi pegawai lain. Setelah dilakukan identifikasi masalah dan melihat alur data yang terbentuk pada sistem berjalan, dibuat estimasi kebutuhan-kebutuhan di dalam mendukung pengembangan sistem serta pembuatan aplikasinya setelah terlebih dulu dibuat alir aplikasi untuk mempermudah melakukan perancangan dan membuat tampilan aplikasi yang diinginkan (Budi, 2002).

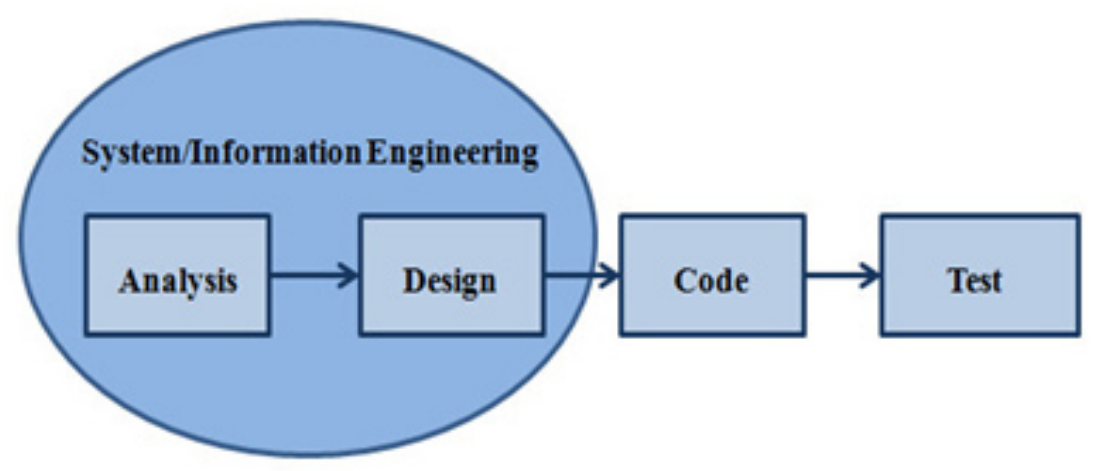

Gambar 1. Pemodelan Sekuensial Linier (Pressman, 2001) 
Pada tahapan ini dilakukan penilaian kinerja pegawai dengan menggunakan analisis Profile Matching untuk mendapatkan nilai dari setiap pegawai yang telah memenuhi syarat administrasi. Pada tahap ini juga telah didefinisikan kriteria yang nantinya digunakan sebagai poin penilaian pegawai terhadap jabatan pada aplikasi sistem penunjang keputusan evaluasi kinerja pegawai. Gambar 2 adalah bagan alur (flowchart) sistem penunjang keputusan promosi jabatan struktural. Selanjutnya, alur kerja penerapan Profile Matching pada Gambar 3.

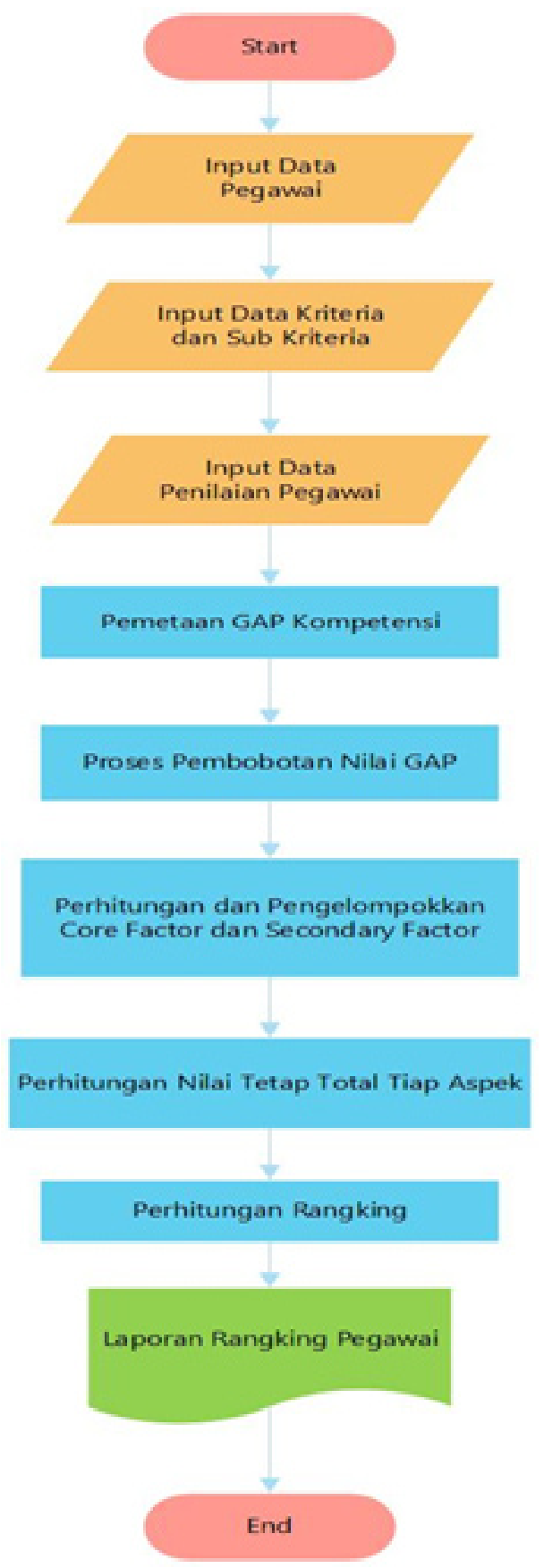

Gambar 2. Flowchart SPK promosi jabatan struktural

\section{HASIL}

\section{Basis Data (Database) Pegawai di PPPPTK Bahasa}

Data penelitian ini berbasis pada data kepegawaian berupa Daftar Urut Kepangkatan (DUK) pegawai PPPPTK Bahasa. Daftar tersebut (DUK) adalah suatu daftar yang memuat nama pegawai dan satuan organisasi Negara yang disusun menurut tingkat kepangkatannya. Ia juga memuat data penting seorang pegawai, yakni nama, NIP, tempat dan tanggal lahir, pangkat dan golongan, nama jabatan, jenis kelamin, tahun masuk pegawai, dan pendidikan terakhir. Daftar tersebut disusun setiap tahun secara rutin dan harus sudah selesai dibuat pada setiap akhir Desember.

Nama pegawai yang akan dipromosikan menduduki jabatan struktural diambil dari DUK tersebut sesuai dengan persyaratan promosi jabatan struktural eselon IV, yaitu (1) minimal berpangkat Penata Muda Tk. I, golongan ruang III/b, masa kerja dalam pangkat terakhir sekurang-kurangnya 2 (dua) tahun, (2) berusia setinggitingginya 51 (lima puluh satu) tahun, (3) berpendidikan serendah-rendahnya Sarjana Muda/Diploma III (D3), dan (4) sehat jasmani dan rohani. Pada penelitian ini terdapat 30 pegawai yang memenuhi persyaratan di atas. Perlu dinyatakan bahwa DUK ini merupakan data utama yang digunakan dalam penelitian ini, lalu ditambah data dan nilai kriteria yang diperoleh dari kuesioner. Selanjutnya, data tersebut diproses melalui komputerisasi menggunakan aplikasi sistem pendukung keputusan hingga memperoleh keluaran berupa nilai pegawai dengan pemeringkatan.

Basis data (database) yang dihasilkan adalah sebagai berikut. Pertama, setelah semua data pegawai dimasukkan ke dalam sistem, data pegawai tersebut akan tersimpan dalam sistem dan dapat dicari dengan mudah apabila diperlukan, sebagaimana dalam matriks Gambar 4. Kedua, data pegawai dalam sistem menjadi induk (master) data kepegawaian yang selanjutnya dapat digunakan untuk memproses nilai pegawai dalam rangka promosi jabatan pegawai. Nilai evaluasi pegawai PPPPTK Bahasa tersimpan dengan baik dalam sistem penunjang keputusan yang akan menjadi basis data yang dapat digunakan untuk membantu pimpinan dalam pengambilan keputusan dan acuan dalam melakukan penilaian pegawai pada tahun-tahun mendatang. Data tersebut dapat dicetak dalam format pdf dan excel. 


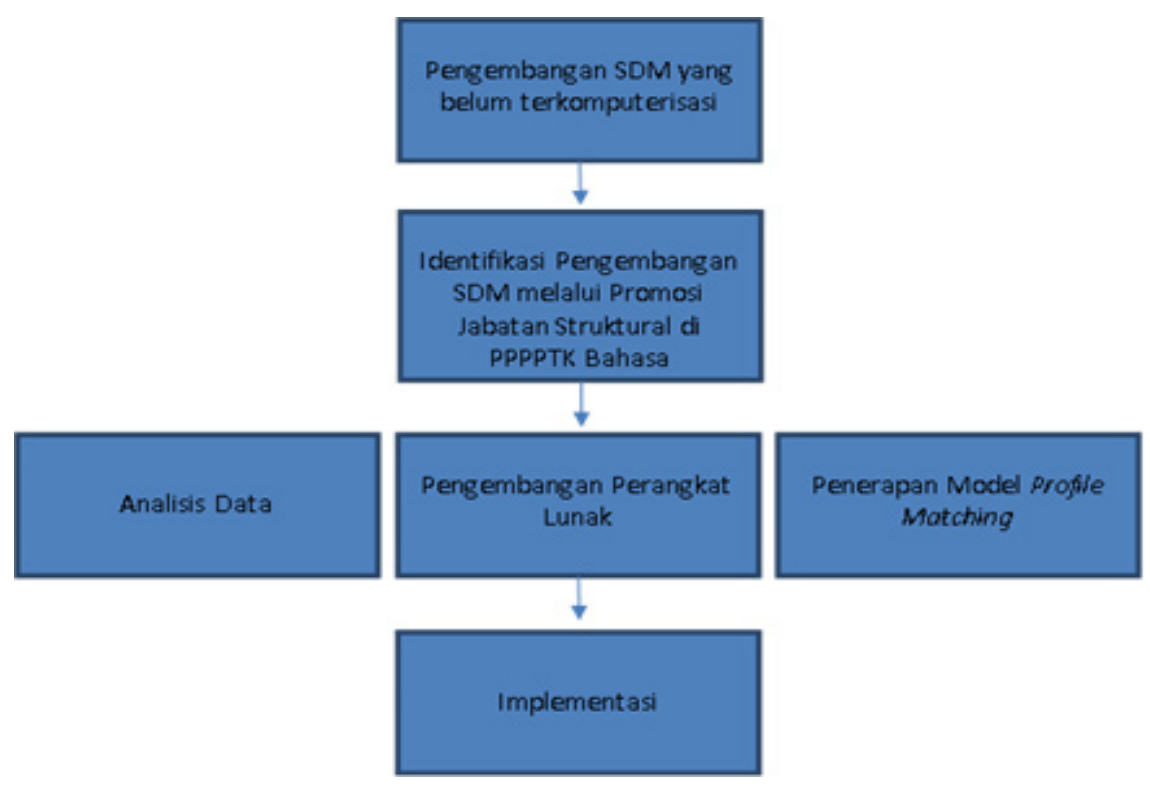

Gambar 3. Alur kerja penerapan profile matching

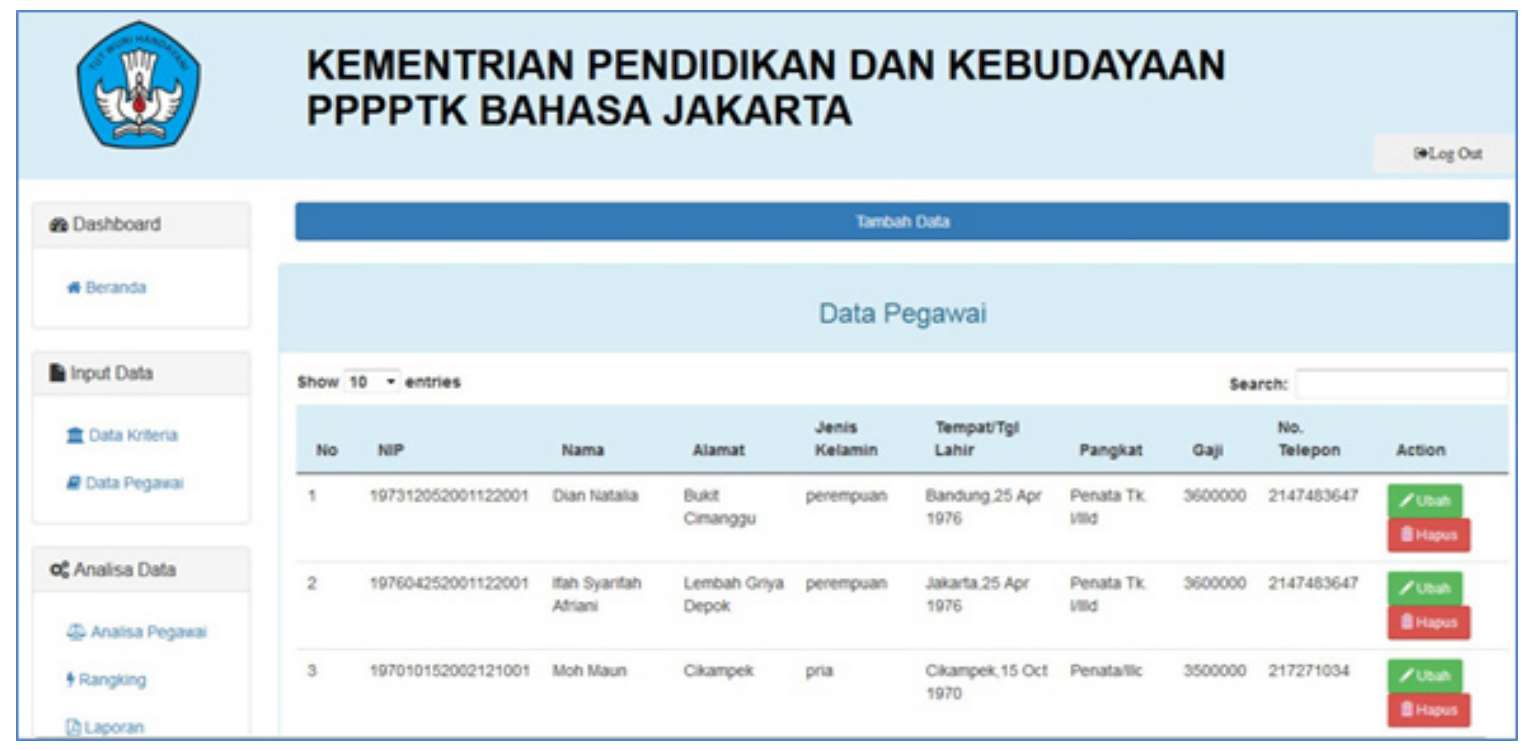

Gambar 4. Data pegawai yang tersimpan dalam sistem yang sudah dibangun

Dengan mekanisme tersebut, penelitian ini menghasilkan basis data pegawai PPPPTK Bahasa yang akan dipromosikan menduduki jabatan struktural berupa kumpulan data yang terorganisasi dengan baik. Koleksi data ini kemudian dimodelkan berdasarkan berbagai aspek dalam dunia nyata, yang pada akhirnya akan mempermudah kita dalam mengambil informasi itu kembali untuk digunakan juga untuk pengembangan karier pegawai lainnya yang dipilih berdasarkan nilai pegawai yang diproses dengan sistem.

\section{Sistem Penunjang Keputusan dalam Proses Promosi Jabatan di PPPPTK Bahasa}

Pengelolaan sumber daya manusia pada PPPPTK Bahasa sangat mempengaruhi keberhasilan kinerja lembaga, khususnya untuk meningkatkan sumber daya manusia. Untuk itu, diperlukan pegawai yang memiliki kemampuan sesuai dengan peran jabatan yang diduduki dan dapat menjalankan tugas pekerjaan dengan penuh tanggung jawab. Pemanfaatan teknologi informasi dengan pengembangan sistem pendukung keputusan dalam proses promosi jabatan struktural di PPPPTK Bahasa menghasilkan informasi berupa alternatif yang dapat membantu pimpinan lembaga dalam mengambil keputusan. 
Proses promosi pegawai dengan informasi yang akurat tentang kandidat pegawai yang akan dicalonkan, dan data pegawai yang relatif cukup banyak dapat terorganisasi dalam satu basis data yang mudah untuk diakses. Pengambilan keputusan dalam suatu organisasi dapat dikatakan suatu hasil proses komunikasi dan partisipasi yang terus-menerus dari keseluruhan organisasi. Hasil keputusan tersebut dapat merupakan pernyataan yang disetujui antar alternatif atau antar prosedur untuk mencapai tujuan tertentu. Persoalan pengambilan keputusan pada dasarnya adalah bentuk pemilihan dari berbagai alternatif tindakan yang mungkin dipilih yang prosesnya melalui mekanisme tertentu dengan harapan menghasilkan sebuah keputusan yang terbaik. Sistem penunjang keputusan promosi jabatan struktural PPPPTK Bahasa dengan metode Profile Matching berhasil dibangun sesuai tujuan awal. Untuk itu, penghitungan Profile Matching terdiri dari lima langkah berikut.

\section{Pemetaan Gap Kompetensi}

Gap dalam konteks ini adalah perbedaan antara profil jabatan dan profil pegawai. Profil pegawai diperoleh dari hasil kuesioner, lalu dibandingkan dengan profil jabatan yang telah ditetapkan berikut skornya. Sebagaimana dinyatakan sebelumnya, faktor penilaian yang digunakan untuk menetapkan profil jabatan dalam penelitian ini adalah Pengetahuan dan Budaya Perusahaan (BP), Kemampuan (KM), dan Kepribadian (KP). Dari setiap kriteria ditentukan bobot, dengan bobot total dari keseluruhan kriteria adalah $100 \%$. Bobot tersebut digunakan berdasarkan tingkat kepentingan dalam penilaian evaluasi kinerja pegawai adalah Pengetahuan dan Budaya Perusahaan
(30\%); Kemampuan (40\%), dan Kepribadian (30\%). Kriteria yang digunakan dalam perhitungan penilaian gap kompetensi terdiri dari beberapa subkriteria dan parameter. Sebagai contoh dapat diambil kriteria kemampuan sebagai kriteria yang memiliki bobot persentase terbesar. Kriteria kemampuan ini digunakan untuk mengukur kemampuan manajerial pegawai. Kriteria kemampuan terdiri dari 6 subkriteria seperti pada kuesioner serta penentuan Core Factor dan Secondary Factor dari subkriteria, sebagaimana Tabel 1. Berdasarkan tabel tersebut, dapat ditentukan parameter dan skor untuk setiap subkriteria adalah Sangat Memuaskan (5); Memuaskan (4); Baik (3); Cukup (2); Kurang (1).

Dari Tabel 2, dapat dilihat bahwa nilai profil pegawai yang diperoleh dari kuesioner adalah 4,4,4,4,4,3; dan nilai profil jabatan yang telah ditetapkan untuk kriteria kemampuan adalah 5,5,5,4,4,4. Dengan demikian, nilai gap kriteria kemampuan untuk pegawai dengan NIP tersebut adalah $-1,-1,-1,0,0$, dan -1 . Proses yang sama juga dilakukan untuk kriteria pengetahuan dan budaya perusahaan serta kriteria kepribadian.

\section{Pembobotan Gap}

Setelah diperoleh nilai gap pada setiap pegawai, setiap profil pegawai diberikan bobot nilai gap dengan mengacu pada tabel bobot nilai (Tabel 3). Dari hasil konversi nilai gap menjadi bobot, diperoleh nilai bobot untuk setiap pegawai. Contoh hasil pembobotan gap kriteria kemampuan pada Tabel 4. Proses yang sama dilakukan untuk menentukan bobot nilai gap dari 2 kriteria lainnya.

Tabel 1. Subkriteria Kemampuan

\begin{tabular}{clccc}
\hline Kode & \multicolumn{1}{c}{ Subkriteria } & Nilai Subkriteria & Bobot (\%) & Keterangan \\
\hline KM001 & Perencanaan, evaluasi, tindaklanjut & 5 & $60 \%$ & Core Factor \\
KM002 & Pengambilan keputusan dan menjelaskan masalah & 5 & $60 \%$ & Core Factor \\
KM003 & Kompetensi & 5 & $60 \%$ & Core Factor \\
KM004 & Pencapaian volume kerja & 4 & $40 \%$ & Secondary Factor \\
KM005 & Peraturan dan Prosedur Kerja & 4 & $40 \%$ & Secondary Factor \\
KM006 & Penyesuaian terhadap keputusan & 4 & $40 \%$ & Secondary Factor \\
\hline
\end{tabular}

Tabel 2. Contoh penentuan nilai gap pada profil pegawai dan profil jabatan

\begin{tabular}{lcccccc}
\hline & KM001 & KM002 & KM003 & KM004 & KM005 & KM006 \\
\hline 197604252001122001 & 4 & 4 & 4 & 4 & 4 & 3 \\
Nilai Subkriteria & 5 & 5 & 5 & 4 & 4 & 4 \\
Nilai Gap & -1 & -1 & -1 & 0 & 0 & -1 \\
\hline
\end{tabular}


Tabel 4. Bobot Nilai GAP

\begin{tabular}{ccl}
\hline Selisih & Bobot Nilai & Keterangan \\
\hline 0 & 6 & Kompetensi sesuai dengan yang dibutuhkan \\
1 & 5,5 & Kompetensi individu kelebihan 1 tingkat/level \\
-1 & 5 & Kompetensi individu kekurangan 1 tingkat/level \\
2 & 4,5 & Kompetensi individu kelebihan 2 tingkat/level \\
-2 & 4 & Kompetensi individu kekurangan 2 tingkat/level \\
3 & 3,5 & Kompetensi individu kelebihan 3 tingkat/level \\
-3 & 3 & Kompetensi individu kekurangan 3 tingkat/level \\
4 & 2,5 & Kompetensi individu kelebihan 4 tingkat/level \\
-4 & 2 & Kompetensi individu kekurangan 4 tingkat/level \\
5 & 1,5 & Kompetensi individu kelebihan 5 tingkat/level \\
-5 & 1 & Kompetensi individu kekurangan 5 tingkat/level \\
\hline
\end{tabular}

Sumber: Handojo et al. (2003).

Tabel 4. Contoh hasil pembobotan gap kriteria kemampuan

\begin{tabular}{lcccccc}
\hline & KM001 & KM002 & KM003 & KM004 & KM005 & KM006 \\
\hline 197604252001122001 & & & & & & \\
Nilai gap & -1 & -1 & -1 & 0 & 0 & -1 \\
Nilai bobot & 5 & 5 & 5 & 6 & 6 & 5 \\
\hline
\end{tabular}

3. Penghitungan Kelompok Nilai Core dan Secondary Factor

Setelah bobot nilai gap untuk setiap kriteria diperoleh, dihitung nilai core factor (CF) dan secondary factor (SF). Kriteria kemampuan yang menjadi subkriteria CF adalah KM001, KM002 dan KM003; dan yang menjadi SF adalah sisanya yaitu KM004, KM005 dan KM00 6.

Penghitungan NCF

$$
\mathrm{NCF}=(\mathrm{KM} 001(5)+\mathrm{KM} 002(5)+\mathrm{KM} 003(5)) / 3
$$$$
\mathrm{NCF}=15 / 3=5
$$

Penghitungan NSF

$\mathrm{NSF}=(\mathrm{KM} 004(6)+\mathrm{KM} 005(6)+\mathrm{KM} 006(5)) / 3$

$\mathrm{NSF}=17 / 3=5,667$

\section{Penghitungan Total Nilai Kriteria}

Setelah diperoleh nilai core factor (CF) dan secondary factor (SF), nilai total kriteria dihitung berdasarkan persentase dari core factor (CF) dan secondary factor (SF) yang diperkirakan berpengaruh pada kinerja setiap profil. Proses yang sama dilakukan untuk menentukan nilai total kriteria lainnya. Untuk lebih jelasnya, penghitungan nilai total dapat dilihat pada contoh penghitungan variabel Kemampuan dengan nilai persentase $60 \%$ dan $40 \%$ berikut:
$\mathrm{N}($ kriteria $)=(60 \% \times 5)+(40 \% \times 5,667)$

$$
=3+2,27=5,27
$$

\section{Penghitungan Penentuan Peringkat (ranking)}

Hasil akhir dari proses Profile Matching adalah pemeringkatan (ranking). Tabel 5 menunjukkan bahwa pegawai dengan NIP 197305062001122001 menduduki peringkat pertama sebagai kandidat terbaik. Contoh Penghitungan :

$$
\begin{aligned}
\mathrm{Ha} & =(30 \% \times 5,30)+(40 \% \times 5,27)+(30 \% \times 5,80) \\
& =1,59+2,10+1,74=5,43
\end{aligned}
$$

\section{Implikasi Manajerial}

Langkah awal yang dapat dilakukan oleh PPPPTK Bahasa dalam rangka proses promosi pejabat struktural adalah melakukan pembenahan internal yang berada dalam organisasi itu sendiri. Hal tersebut dapat dilakukan dengan meningkatkan kualitas sumber daya manusia dan memanfaatkan teknologi informasi dalam pengelolaan data; sehingga menghasilkan informasi yang akurat di PPPTK Bahasa Jakarta. Dengan demikian, perubahan pada sistem proses promosi jabatan struktural PPPPTK Bahasa Jakarta menjadi terkomputerisasi. 
Tabel 5. Hasil dari proses Profile Matching seluruh responden

\begin{tabular}{ccccc}
\hline NIP & $\begin{array}{c}\text { NT } \\
(\mathrm{bp})\end{array}$ & $\begin{array}{c}\text { NT } \\
(\mathrm{km})\end{array}$ & $\begin{array}{c}\text { NT } \\
(\mathrm{kp})\end{array}$ & Skor \\
\hline 197305062001122001 & 5,80 & 5,80 & 5,80 & 5,800 \\
198012182005012002 & 5,85 & 5,47 & 5,80 & 5,682 \\
198303082010122006 & 5,55 & 5,53 & 5,80 & 5,618 \\
197607222002122002 & 5,85 & 5,40 & 5,60 & 5,595 \\
197905142005012001 & 5,85 & 5,13 & 5,80 & 5,548 \\
197412302002122001 & 5,40 & 5,40 & 5,80 & 5,520 \\
196809272002121001 & 5,30 & 5,53 & 5,70 & 5,513 \\
197010152002121001 & 5,50 & 5,40 & 5,60 & 5,490 \\
197901272002122003 & 5,50 & 5,27 & 5,70 & 5,467 \\
197604252001122001 & 5,30 & 5,27 & 5,80 & 5,437 \\
198210302006042001 & 5,30 & 5,27 & 5,80 & 5,437 \\
197806202001122003 & 5,25 & 5,33 & 5,60 & 5,388 \\
197611192002121002 & 5,60 & 4,87 & 5,80 & 5,367 \\
197608102005011002 & 5,60 & 5,00 & 5,60 & 5,360 \\
198107192005012003 & 4,85 & 5,40 & 5,80 & 5,355 \\
197208272001121001 & 5,10 & 5,20 & 5,80 & 5,350 \\
197512012006042002 & 5,40 & 5,40 & 5,20 & 5,340 \\
198101042009122002 & 4,85 & 5,20 & 5,80 & 5,275 \\
197805132006042001 & 5,20 & 5,07 & 5,60 & 5,267 \\
197412232002121001 & 4,90 & 5,00 & 5,80 & 5,210 \\
197601122005012001 & 4,80 & 4,73 & 5,80 & 5,073 \\
197609282002122001 & 4,80 & 4,87 & 5,60 & 5,067 \\
197606112006042004 & 4,80 & 4,67 & 5,80 & 5,047 \\
198205222009122001 & 4,50 & 5,07 & 5,40 & 4,997 \\
197403312006042001 & 4,85 & 4,73 & 5,40 & 4,968 \\
197312052001122001 & 4,60 & 4,73 & 5,40 & 4,893 \\
198004232005012002 & 4,70 & 4,40 & 5,30 & 4,760 \\
196706292001121001 & 4,40 & 4,40 & 5,20 & 4,640 \\
197909282006041002 & 4,40 & 4,40 & 5,20 & 4,640 \\
198504022010121005 & 3,90 & 3,93 & 5,00 & 4,243 \\
\hline & & & & \\
\hline
\end{tabular}

\section{KESIMPULAN DAN SARAN}

\section{Kesimpulan}

Sistem pendukung keputusan dalam rangka promosi pegawai berhasil dibangun sesuai dengan perencanaan danmodelnya dengan baik. Kedua, tersedianyabasis data promosi pegawai untuk pengembangan karier pegawai merupakan salah satu tugas pokok dari Subbagian Tatalaksana dan Kepegawaian. Dari kedua simpulan tersebut, dapat dikatakan bahwa sistem penunjang keputusan yang dibangun memiliki kesesuaian dengan hasil penelitian-penelitian sebelumnya.

\section{Saran}

Pemanfaatan teknologi informasi melalui Sistem Penunjang Keputusan ini akan membantu Pimpinan mengambil keputusan dalam proses penilaian pegawai dalam rangka promosi jabatan. Program ini berhasil diimplementasikan dengan baik disarankan untuk dikembangkan berbasis web sehingga dapat saling berinteraksi dengan sistem informasi yang sudah ada. Dalam pengembangan sistem selanjutnya penilaian kinerja bukan hanya untuk pegawai yang akan dipromosikan melalui diklat PIM IV melainkan juga untuk semua pejabat eselon yang akan mengikuti diklat PIM II dan III. Penelitian selanjutnya dapat dilakukan dengan membuat program yang lebih fleksibel dengan menambah atau mengurangi kriteria sesuai dengan kebutuhan penilaian. Penelitian ini hanya membahas proses promosi jabatan melalui diklat PIM IV. Peneliti lain disarankan melakukan penelitian secara lebih mendalam dengan mengambil peserta diklat PIM di atasnya, yakni PIM II dan III sebagai data.

\section{DAFTAR PUSTAKA}

Ariantono HP. 2015. Rancang bangun sistem penunjang keputusan penentuan kenaikan posisi jabatan pada instansi pemerintahan dengan metode profile matching. Jurnal Spektrum 2 (3): 38-43.

Astriratma R, Wardoyo R, Musdholifah A. 2017. Rekomendasi pemilihan kandidat pejabat struktural menggunakan metode profile matching (studi kasus: Pemerintah Kota Tarakan). Indonesian Journal of Computing and Cybernetics Systems 11 (1): 77-88. https://doi. org/10.22146/ijccs.17342.

Budi SD. 2002. Perencanaan dan Pengembangan Sistem Informasi. Edisi ke-1. Yogyakarta: Andi.

Deny A. 2014. Sistem pendukung keputusan pengangkatan jabatan karyawan pada PT. Ayn dengan metode profile matching. Jurnal Jatisi 1(1): 16-29.

Firman W. 2014. Peran kompetensi dalam meningkatkan kinerja pegawai bagian sosial sekretariat Daerah Kabupaten Kutai Timur. E-Journal Administrative Reform 2(1): 1047-1060.

Frieyadie. 2016. Penggunaan metode profile matching untuk sistem penunjang keputusan kenaikan jabatan pada instansi pemerintah. Jurnal Paradigma XVIII(2): 75-80.

Hadari N. 2003. Metode Penelitian Bidang Sosial. 
Yogyakarta: UGM Press.

Handayani RI. 2017. Sistem pendukung keputusan pemilihan karyawan berprestasi dengan metode profile matching pada PT. Sarana Inti Persada (SIP). Jurnal Pilar Nusa Mandiri 13(1): 28-34. https://doi.org/10.33372/stn.v3i1.197.

Handojo A, Djoni HS, Rachma Y. 2003. Pembuatan aplikasi sistem pendukung keputusan untuk proses kenaikan jabatan dan perencanaan karir Pada PT. X. Jurnal Informatika 4 (2): 101-105.

Hidayat, Arif L, Tito P. 2013. Sistem pendukung keputusan evaluasi kinerja karyawan untuk promosi jabatan struktural pada bimbingan belajar science master menggunakan metode gap kompetensi (profile matching). Jurnal Teknologi Technoscientia 5(2): 211-220.

Jogiyanto HM. 2005. Analisis dan desain Sistem Informasi. Yogyakarta: Andi.

Kristiana T. 2015. Penerapan profile matching untuk penilaian kinerja pegawai negeri sipil (PNS). Jurnal Pilar Nusa Mandiri XI (2): 161-170.

Kusnadi, Deny M, Aji S. 2015. Penerapan metode profile matching untuk penilaian kenaikan jabatan karyawan (studi kasus PT. Ilham Bangun Mandiri). Jurnal Digit 5(2): 146-158.

Kusrini. 2007. Aplikasi Pendukung Keputusan. Yogyakarta: Andi.

Lestari W. 2016. Perancangan aplikasi peningkatan jenjang karir menggunakan metode profile matching (studi kasus: CV. Indasco Tranding Company). Jurnal Infotek 1(3): 201-205.

Muchsam Yoki, Falahah, Galih IS. 2011. Penerapan gap analysis pada pengembangan sistem pendukung keputusan penilaian konerja karyawan (studi kasus di PT. XYZ). Seminar Nasional Aplikasi
Teknologi Informasi (SNATI) 17-18 Juni 2011. A94-A100.

Muqtadir A, Purdianto I. 2013. Sistem pendukung keputusan kenaikan jabatan menggunakan metode profile matching (studi kasus di PT. Industri Kemasan Semen Gresik). Seminar Nasional Aplikasi Teknologi Informasi (SNATI), hlm 48-55.

Palandi JF, Pudyastuti ZE. 2014. Penyaringan kandidat untuk promosi jabatan dengan profile matching. Dinamika Dotcom 5(1): 40-51.

Pressman RS. 2001. Software Engineering: A Practitioner's Approach, Fifth Ed. New York, McGraw-Hill Book Company.

Puspitasari L. 2013. Penerapan metode profile matching dalam sistem pendukung keputusan penilaian kinerja karyawan (studi kasus di PT. Perkebunan Nusantara III Medan). Jurnal Informatika Budi Darma V(3).

Qomayati. 2010. Sistem Pendukung Keputusan Kenaikan Jabatan Pada PT. SC Enterprises Semarang. 2010. Semarang: Universitas Dian Nuswantoro.

Rivai V. 2005. Manajemen Sumber Daya Manusia untuk Perusahaan, dari Teori ke Praktik. Jakarta: Raja Grafindo Persada.

Schermerhorn RJ, Hunt GJ, Osborn NR. 1996. Organizational Behavior. 6th Editon. New York: John Wiley \& Son.

Sjafri M. 2009. Horison-Bisnis, Manajemen, dan Sumber Daya Manusia. Cetakan Kedua. Bogor: IPB Press.

Sumarwan U. 2011. Perilaku Konsumen. Bogor: Ghalia Indonesia. 